\title{
The Potential Effect of Pests on Forest Fire: Flammability of Mongolian Pine Bark with Resinosis on Boles
}

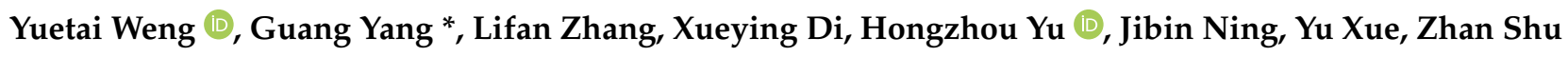 \\ and Dongdong Han
}

check for

updates

Citation: Weng, Y.; Yang, G.; Zhang, L.; Di, X.; Yu, H.; Ning, J.; Xue, Y.; Shu, Z.; Han, D. The Potential Effect of Pests on Forest Fire: Flammability of Mongolian Pine Bark with Resinosis on Boles. Forests 2021, 12, 365. https://doi.org/10.3390/f12030365

Academic Editor: Mohammad M. Bataineh

Received: 20 January 2021

Accepted: 16 March 2021

Published: 19 March 2021

Publisher's Note: MDPI stays neutral with regard to jurisdictional claims in published maps and institutional affiliations.

Copyright: (c) 2021 by the authors. Licensee MDPI, Basel, Switzerland. This article is an open access article distributed under the terms and conditions of the Creative Commons Attribution (CC BY) license (https:/ / creativecommons.org/licenses/by/ $4.0 /)$.
Key Laboratory of Sustainable Forest Ecosystem Management, Ministry of Education, School of Forestry, Northeast Forestry University, Harbin 150040, China; wyt2016@nefu.edu.cn (Y.W.); lzg@nefu.edu.cn (L.Z.); dixueying@nefu.edu.cn (X.D.); yhz_nefu@nefu.edu.cn (H.Y.); ningjibin@nefu.edu.cn (J.N.); xueyuhenry@gmail.com (Y.X.); shuzhan@nefu.edu.cn (Z.S.); budong@nefu.edu.cn (D.H.)

* Correspondence: yangguang@nefu.edu.cn; Tel.: +86-0451-82-190-656

\begin{abstract}
Wildfires and pests are natural disturbance agents in many forest ecosystems that often contribute to ecological succession, nutrient cycling, and forest species composition. Mongolian pine (Pinus sylvestris var. mongolica) is a coniferous species that plays an important role as an ecological barrier, and is widely spread in northern China. Its wood is loose; its branches, leaves, and cones contain a high level of resin and volatile oils that make the species highly flammable and the stands dominated by the species are very vulnerable to fire. Recently, resinosis on boles of Pinus sylvestris became an epidemic in China. To explore the potential effects of pests on fire, we compared the flammability of Mongolian pine barks with or without resinosis on boles using a cone calorimeter and several combustion analyses. We found that the barks from boles with resinosis had a greater oil content than the healthy trees. The study also indicated that the ignition times of the barks from boles with and without resinosis were $6.00 \mathrm{~s}( \pm 1.73)$ and $22.67 \mathrm{~s}( \pm 1.15)$, respectively, and that the heat release rate curves were parabolic, with peaks 225.19 and $75.27 \mathrm{~kW} / \mathrm{m}^{2}$, respectively, for the two bark types. Additionally, because resinosis was on the low- to mid-bole of infested trees, the barks from boles with resinosis tended to be ignited much easier than those without resinosis. This clearly evidenced that pests could affect fire severity and behavior by increasing forest flammability. More information about the role that pests play in the different forest cover types is needed to increase our understanding of fire danger and to develop sound forest management policies.
\end{abstract}

Keywords: resinosis; fire severity; fire intensity; combustibility; tree bark; fuel; Pinus sylvestris var. mongolica

\section{Introduction}

Mongolian pine (Pinus sylvestris var. mongolica (MP)) is a geographical variety of Scots pine (Pinus sylvestris). It is a widely distributed and strongly cold- and drought-resistant coniferous species found in Northeast Asia, including Mongolia and adjoining parts of southern Siberia and northern China [1-4]. MP is one of the principal tree species found in the Three-North Shelterbelt Forest Project that was established for windbreak and sand stabilization, and had a distribution area of up to $1309.74 \mathrm{~km}^{2}$ in northern China in 2015 [5]. MP forests have brought excellent ecological, economical, and social benefits to the sandy lands in China's semiarid regions, and have played an important role in afforesting and building green ecological shelters. Large-scale afforestation with MP is still underway in northern China [6].

To make MP a suitable species for shelter forest plantation, most previous studies on MPs have primarily focused on its physiology, ecology, hydrology, pest/disease prevention, and cultivation techniques [7-9]. The decline of MP forests in northern China has caused serious ecological concerns; thus, to deal with the decline, many possible explanations have been proposed [3,10]. Changing climate and land-use are altering fire regimes and 
are increasing pest risks and fire severity [11-13], and ecosystems, such as MP plantations, that display poor resistance to disturbances may become even more vulnerable and prone to decline if the fire and pest risks increases.

Wildfires are one of the major disturbances in forest ecosystems, which has become a severe global problem that poses severe threats to the safety of human lives and properties, as well as to the economy and the environment. MP is a flammable timber species, with its stem, branches, needle leaves, and cones containing high levels of resin and other volatile oils; hence, the susceptibility of MP plantations to pests and fire hazards is often high [14].

The largest natural distribution area of MPs in China is found in the Hulun Buir administrative region, specifically, the Honghuaerji Mongolian Pine National Nature Reserve (see Figure 1), which is an important germplasm resource of MP. The climate in the Honghuaerji Reserve is dry and windy, and has the highest frequency of lightningcaused forest fires in China. According to records of pest outbreaks and fires, several pest outbreaks and seven large forest fires occurred in the aforementioned areas from 1994 to 2006. In such an environment, the interaction between wildfires and pests in MP stands should receive more attention in order to keep MP forests healthy and productive.
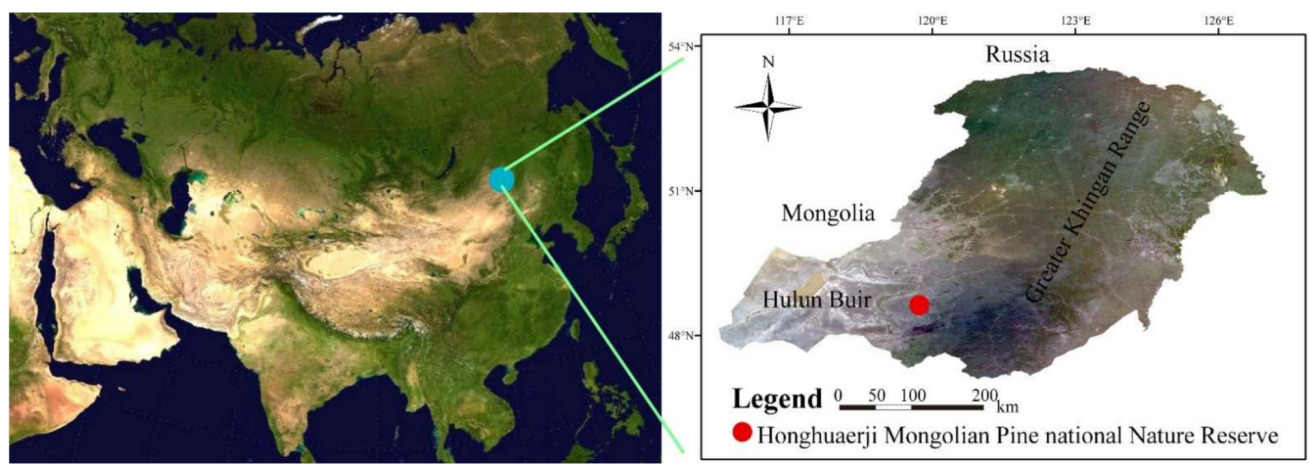

Figure 1. Location map of the study area in China.

The effects of wildfire and pests have interacted for a long time to produce a forested landscape dominated by seral or pioneering species of conifers. A number of studies on pest outbreaks in ecosystems after a forest fire have been carried out, but the effects of pests, with the exception of bark beetles, on fire has not been sufficiently studied [15]. Furthermore, differences in the severity of fires often exist in forests, with or without pest outbreaks, in which non-infested stands have a much lower fire severity than infested stands, which is possibly because of the non-infested stands' lower fuel availability and higher resilience to fires [16]. The trees killed by pests create abundant ground fuels; pest outbreaks cause extensive tree mortality and the dead trees become a large contiguous fuel base. However, the mechanism by which pests reduce a tree's fire resistance and increase a tree's mortality has not yet been elucidated.

Bark traits are an important determinant of a tree's resistance to fire [17-20]. Although bark traits appear to be the most important tree traits to be considered for preventing fire-induced mortality, only bark thickness and structure have been explored in numerous studies $[17,21,22]$. Variations in the bark's flammability that are caused by pests may be one of the mechanisms by which pests weaken the fire resistance of trees. Moreover, bark has fundamental functions for trees (water loss reduction, mechanical stability, protection against exterior damage, and insulation of the stem against adverse climatic conditions); hence, it is fatal to trees when tree bark catches on fire.

As global warming becomes more evident, as seen in the increased frequency of extreme weather conditions, resinosis has become a common forest phenomenon in conifer forests. Resinosis is an accumulation of resin in conifers that often arises as a result of an insect or pathogen attack, specifically, wood wasp (Sirex noctilio Fabricius (Hymenoptera: Siricidae)) attack in case of MP [23]. Recently, MP plantations in northeast China have 
been suffering an outbreak of wood wasps, with resin appearing on the low- to mid-bole sections of infested trees (see Figure 2).
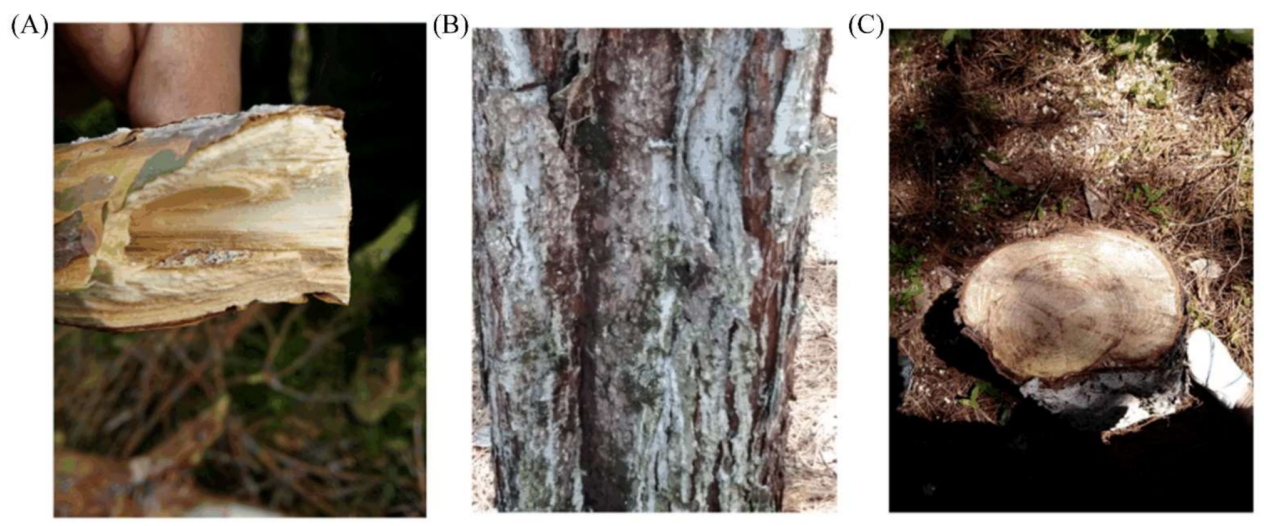

Figure 2. Symptoms of Pinus sylvestris var. mongolica (Mongolian pine (MP)) with resinosis: (A) accumulation of granules of resin and loss of water in the MP bark of twigs; (B) solidification of resin on the bark of an MP tree with resinosis; (C) cross section of MP bole exhibiting a concave shape.

The potential threat caused by the interaction between resinosis and fire to MP forests is the focus of our study. We hypothesized that the pests in MP stands weaken a tree's resistance to fire by altering bark traits, which in turn render the tree more flammable. To test our hypothesis, we compared barks traits from boles of MP with or without resinosis. The findings from this study can be used to protect MP forests and promote the implementation of a shelter forest plantation project in northeastern, northwestern, and northern China.

\section{Materials and Methods}

\subsection{Study Site}

The study area, Honghuaerji Mongolian Pine Nature Reserve, located near the Greater Khingan Range of China, was established in 1998 by the Inner Mongolia Autonomous Region because of its important germplasm resources of MPs. The reserve was then promoted as a National Nature Reserve (NNR) in 2003 by the central government [24]. The reserve is bound by latitude $47^{\circ} 41^{\prime}-48^{\circ} 08^{\prime}$ and longitude $119^{\circ}-125^{\circ} 45^{\prime}$, and the total area of MP forests is approximately $2.5 \times 10^{5} \mathrm{~km}^{2}$. The reserve belongs to the continental monsoon climate in the middle temperature zone, with an annual effective sunshine of $2800 \mathrm{~h}$, annual mean temperature of $-3.6^{\circ} \mathrm{C}$, annual maximum temperature of $40.1^{\circ} \mathrm{C}$, and annual minimum temperature of $-49.3^{\circ} \mathrm{C}$. The annual precipitation is $344 \mathrm{~mm}$, and most precipitation occurs in July and August, while the annual evaporation is $1174 \mathrm{~mm}$ and the aridity index is 1.33. Annually, a west wind dominated; however, during the summer, south and east winds are more frequent. Frost starts in early September and dissapears in early June.

\subsection{Field Sampling and Material Processing}

The field survey took place in 2017. In the survey, we chose three representative MP stands as sample plots; we measured the trees' diameter at breast height (DBH) and determined the stand ages for each plot. All trees in the plots were examined to detect whether they were infected. We selected $61 \mathrm{MP}$ trees with and $27 \mathrm{MP}$ trees without resinosis on their boles from the three representative MP stands, and used a 10-cm-wide steel chisel to collect a bark sample $\left(20 \times 10 \mathrm{~cm}^{2}\right)$ at the disease site (similar site for healthy trees) from each MP tree. We tried to keep the infected trees similar in size (DBH) to the healthy trees. Eighty-eight specimens with bark thickness ranging from 25 to $35 \mathrm{~mm}$ were transported in separate plastic cases to the laboratory. Each of the two groups of samples was randomly and approximately equally divided into three mixed samples. We 
first air-dried the collected materials for 30 days, and then they were paper-bagged and oven-dried at $85^{\circ} \mathrm{C}$ until the dry weight was stabilized. Finally, each mixed sample was ground (20-mesh) with a pulverizer and mixed for further analyses.

\subsection{Measuring Flammability, Oil Content, and Composition of Barks}

Flammability can be described as four components of fuel characteristics that effect fire behavior and probability, which can be measured at different scales and with different metrics $[25,26]$. The cone calorimeter is a widely accepted fire testing apparatus that is used to assess forest fuel flammability, such as pyrolysis, ignition, rate of smoke release, flammability, mass loss rate, heat release rate, fire spread, and so forth $[27,28]$. We conducted flammability tests on each subgroup material using the FTT0007 cone calorimeter (Fire Testing Technology, West Sussex, UK), according to the ISO 5660-1 standard [29]. For each sample, the ground barks were put into a $10 \times 10 \mathrm{~cm}^{2}$ specimen holder after sifting, and three pieces were wrapped with aluminum foil [24]. For the measurement, the temperature of cone calorimeter was set at $780{ }^{\circ} \mathrm{C}$ and the radiation of the heat source was set at $50 \mathrm{~kW} / \mathrm{m}^{2}$. The three healthy and three infested mixed samples were individually measured once and the mean values were taken.

We used the organic solvent extraction method to measure the oil content in both the infected and healthy barks. First, the samples were sifted through a 20-mesh sieve, then $2 \mathrm{~g}$ of the sifted bark samples were put into a conical flask and mixed with $30 \mathrm{~mL}$ petroleum ether; then, we put the conical flask into a cell disruptor (SCIENTZ-IID; Ningbo Xinzhi Biotechnology Co. Ltd., Ningbo, China) for $20 \mathrm{~min}$ for the extraction process. After extraction, we moved the liquid in the conical flask into a centrifuge tube and centrifuged the liquid at $5000 \mathrm{~g} / \mathrm{min}$ for $10 \mathrm{~min}$; the weight of the centrifuged liquid and the weight of the liquid after air-drying were used to derive the percentage of oil content.

The following physical characteristic and compounds of the bark samples were determined: moisture content $(\%)$, ash content $(\%)$, resin content $(\%), 1 \%$ sodium hydroxide extract $(\%)$, holocellulose $(\%)$, pentosane $(\%)$, and both acid-insoluble lignin $(\%)$ and acidsoluble lignin (\%). Technical details for extracting these composites in barks were followed according to the GB/T 2677.2-2011, GB/T742-2008, GB/T 2677.6-1994, GB/T2677.5-1993, GB/T2677.10-1995, GB/T2677.9-1994, GB/T2677.8-1994, and GB/T10337-2008 standards in China.

\subsection{Combustion Analyses}

Heat release rate (HRR) is the heat available in every unit area of surface absorbing heat within a particular surface, and it reflects the rate of heat generated by fire. As the HRR increases, the heating being generated by the material surface burning, the pyrolysis rate of the burning material, and the amount of volatile material released by burning all also increase, accelerating the fire spread. HRR curves are made for both infected and healthy trees; the curves are capable of showing any differences in flammability characteristics for both infected and healthy trees.

Another commonly used flammability parameter is the mass loss rate (MLR), which refers to the rate at which mass changes per unit area and unit time during burning. This parameter also measures the degree of volatilization, pyrolysis, and burning of fuel at a given fire intensity. MLR curves relate MLR to time after ignition; the MLR curves for infected and healthy trees can also be used to discern any flammability differences for the two types of trees.

Ignition time (IT) is the time until ignition from the beginning of heating for a fuel to burn with a stable flame [25]; IT is an important index to assess a material's flammability. Experiments were conducted to calculate the ITs for both infected and heathy trees; the differences between the two ITs revealed combustion differences from another aspect. Total heat release (THR) is the accumulation of heat generated per unit area from the start of burning to the end of burning. Analyzing both HRR and THR together reveals the flammability of a fuel more objectively and comprehensively. Combustion differences were 
expected in the THRs for both infected and healthy trees, and THR curves were prepared for both infected and healthy trees. Fire occurrence index (FOI) is often used to assess a material's fire hazard; FOI is defined as the ratio between IT and the peak of HRR. For a fuel, a larger FOI value suggests a higher fire resistance, while a smaller FOI value signifies a lower fire resistance.

All statistical analyses were conducted using SPSS 24.0 statistical software (SPSS, Chicago, IL, USA). We conducted a t-test to determine if there were statistically significant differences between the FOIs of infected trees and healthy trees. We also conducted a t-test and Pearson correlation to determine if there were statistically significant differences or correlations between the FOI and bark compositions of infected trees and healthy trees. Such analyses can disclose which composites are favorable for ignition and which are not.

\section{Results}

Compared with healthy trees, the barks of infected trees contained a large amount of resin and oil, indicating that a decline of disease increased the bark's oil content substantially. We conducted a T-test to determine if there were statistically significant differences between the two groups, with or without resinosis on boles, of the barks from the MP stands. The average oil content of the healthy MP tree barks was $4.0( \pm 0.29) \%$, which is significantly smaller than $24.5( \pm 1.0) \%(p<0.001)$, which was the average bark oil content of MP with resinosis on their boles. In other words, barks from the MP trees with resinosis on their boles were more susceptible to ignition compared with the healthy MP trees.

Figure 3 consists of the mean HRR over heating time curves for both groups of barks from MP, with and without resinosis on boles, and the curves are parabolic with peaks. The horizontal axis (heating time) represents the time for sustained ignition of the test sample. The mean peak values were $225.19 \mathrm{~kW} / \mathrm{m}^{2}, 70 \mathrm{~s}$ after ignition and $75.27 \mathrm{~kW} / \mathrm{m}^{2}, 50 \mathrm{~s}$ after ignition, for both infected and heathy tree barks, respectively. The curves show that the HRR of barks from the infected trees were substantially greater than those from the healthy trees for the duration of 0 to $325 \mathrm{~s}$ after ignition. Thus, the results indicated that a high content of resin and oil in the tree's bark could increase forest flammability; therefore, MP stands with infected trees face a higher fire hazard than healthy MP stands.

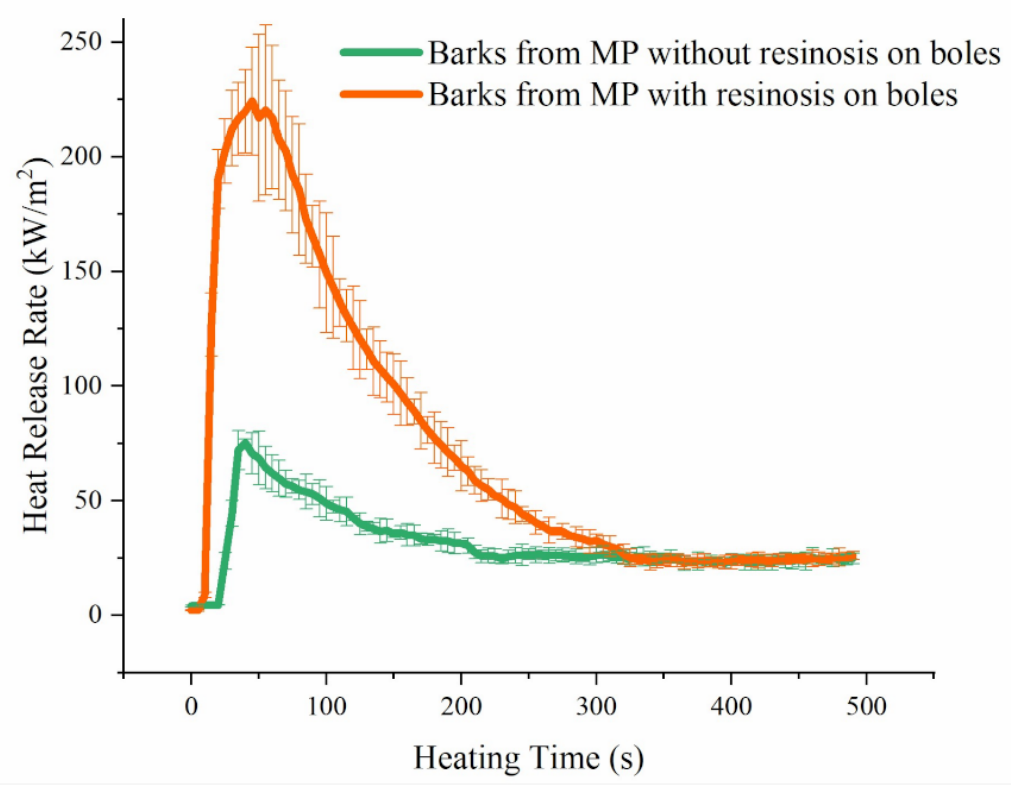

Figure 3. Heat release rate curves for barks of Pinus sylvestris with and without resinosis on boles. All materials were sifted through a 20-mesh sieve. Curves show the mean of all of the tests in each group. The horizontal axis represents the time for sustained ignition of the test sample. Whiskers indicate \pm 1 standard errors of the mean. 
Figure 4 contains the mean MLR curves that changed with heating time for both groups of barks from the infected and healthy MP trees. As the curves show, the mass loss rate for barks from the healthy MP trees were much smaller than that from the infected MP trees for the duration of 0 to $200 \mathrm{~s}$ after ignition. This indicates that the infected tree barks may have contained a larger proportion of flammable chemical constituent sensitive to pyrolysis. Thus, the barks of MP trees with resinosis on boles burned faster than that of the healthy tress.

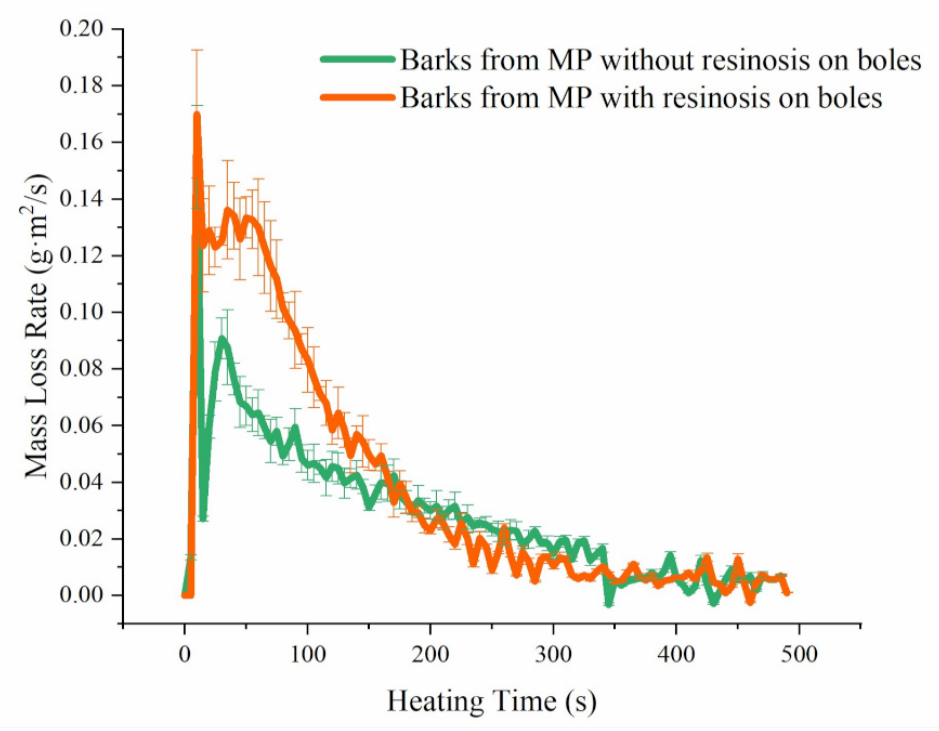

Figure 4. Mass loss rate (MLR) curves of barks from MP with and without resinosis on the boles. Curves show the mean of all of the samples in each group. The horizontal axis represents the time for sustained ignition of the test sample. Whiskers indicate \pm 1 standard errors of the mean.

Table 1 shows the results for the test we conducted on the ignition time for the bark samples. As the table indicates, the times to ignition were $6.00 \pm 1.73 \mathrm{~s}$ and $22.67 \pm 1.15 \mathrm{~s}$ for the two groups of MP tree barks, and the t-test detected a significant difference between the two means $(p<0.001)$. We also tested the time of extinction for the two bark types-303.00 $\pm 33.14 \mathrm{~s}$ for the infected trees barks and $285.67 \pm 38.63 \mathrm{~s}$ for healthy trees barks-and there was no significant difference found $(p=0.093)$. These results show that although resinosis affects a bark's ignition time, it has no significant effect on the time of extinction.

Table 1. Heating process of Pinus sylvestris var. mongolica barks of healthy and infected stems.

\begin{tabular}{ccc}
\hline Sample & Time to Ignition (s) & Time of Extinction (s) \\
\hline Barks from MP without resinosis & $22.67 \pm 1.15$ & $285.67 \pm 38.63$ \\
Barks from MP with resinosis & $6.00 \pm 1.73$ & $303.00 \pm 33.14$
\end{tabular}

Note: Experimental conditions were as follows: the temperature of cone calorimeter was set at $780^{\circ} \mathrm{C}$ and the radiation of heat source was set at $50 \mathrm{~kW} / \mathrm{m}^{2}$.

We generated mean THR curves that changed with heating time for the two types of tree barks and the curves are presented in Figure 5. As shown, the THR of the infected tree barks was consistently greater than that of the healthy tree barks, and the two THRs achieved their maximum values at a heating time of $500 \mathrm{~s}$, which were $36.59 \mathrm{MJ} / \mathrm{m}^{2}$ for the infected tree bark and $15.63 \mathrm{MJ} / \mathrm{m}^{2}$ for healthy tree bark. Both curves had the heatreleasing characteristics of an early and fast acceleration, which later on slowed down in the test. The results of the THR and HRR tests further confirmed that in terms of the heat released during ignition, the infected tree barks released much more heat than the healthy tree barks; therefore, the lower resin and oil content in the tree barks should help forest fire prevention. 


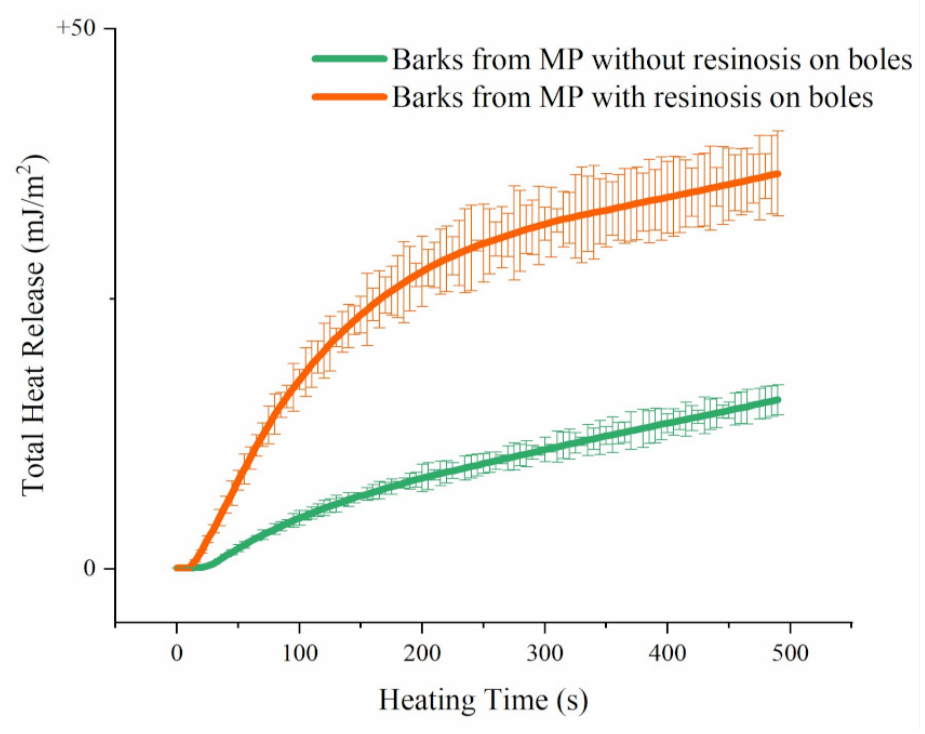

Figure 5. Total heat release (THR) curves of the barks from MP with and without resinosis on boles. The curves show the mean of all of the tests in each group. The horizontal axis represents the time for the sustained ignition of the test sample. Whiskers indicate \pm 1 standard errors of the mean.

The FOI was computed for the two types of tree barks. As Figure 6 suggests, the FOI for healthy tree bark was 0.297 , which was significantly greater than $0.026(p=0.039)$, which was the FOI value for the infected tree bark. Because larger FOI values represent higher fire resistance and vice versa, the FOI test results indicated that the bark of MP with resinosis on boles would make trees susceptible to forest fires. In addition, we calculated the Pearson correlation coefficient between FOI and the other bark compounds; the coefficients are presented in Figure 7. The correlation between FOI and the moisture, resin, and alkali extractive were negative, with coefficient values of $-0.995,-0.998$, and -0.999 , respectively, at $p<0.05$. The correlation between FOI and the ash, holocellulose, lignin, and acid-insoluble lignin were positive, with coefficient values of $0.978,0.999,0.975$, and 0.994 at $p<0.05$, respectively.

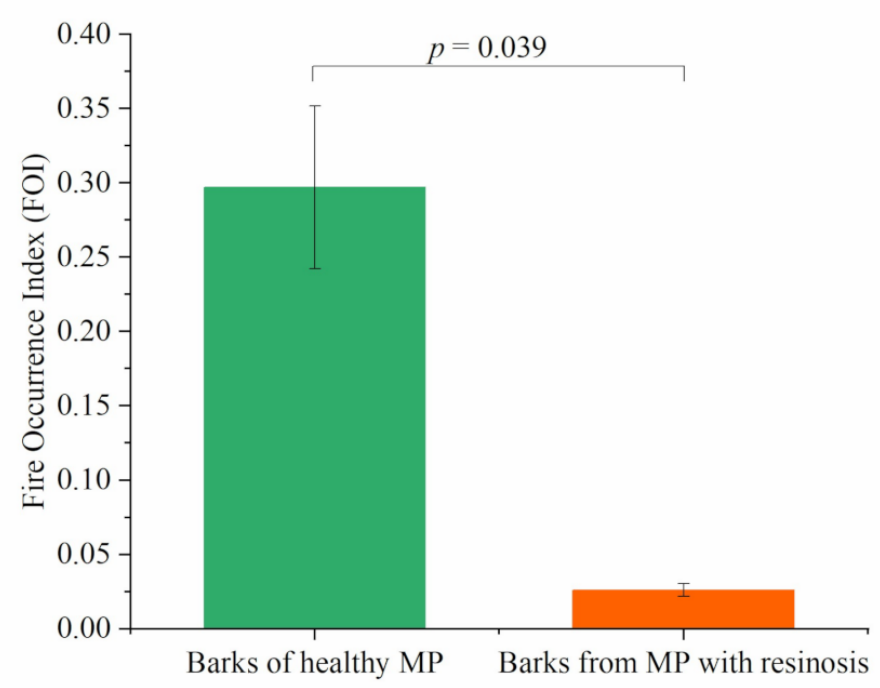

Figure 6. Comparation of the fire occurrence indexes (FOIs) of barks from MP with and without resinosis on boles. Whiskers indicate \pm 1 standard errors of the mean. 


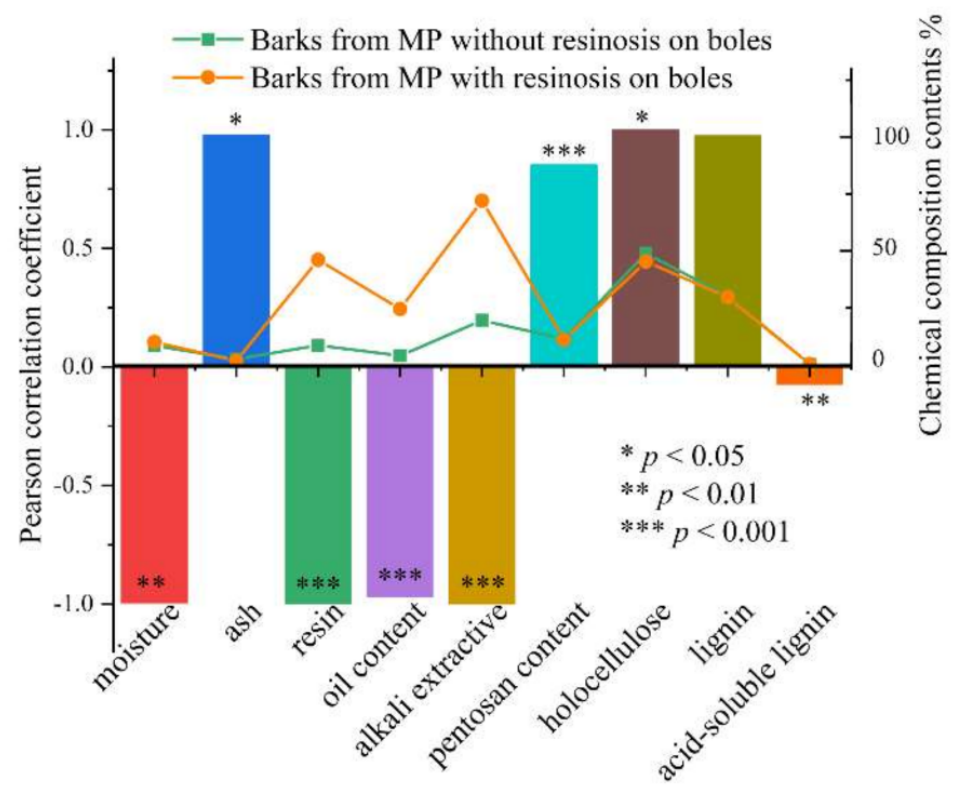

Figure 7. Chemical composition contents of barks from MP with/without resinosis on boles, and an analysis of the correlations between the MP bark chemical composition and FOI. The colored column heights reflect the Pearson correlation coefficient. Colored points represent chemical composition contents $(\%)$ and the values are the means.

\section{Discussion}

\subsection{Effects of Pests on Fuels}

Biomass is the material basis of fire and is necessary for the survival of pests. The change in the behavior of pests to biomass is the theoretical basis for the influence of pests on forest fires, and there is a complex relationship between fire and pests. Fires can affect the survival and occurrence conditions of forest pests; similarly, pests can also affect the frequency and intensity of forest fires by changing the characteristics and distribution of fuels [30]. This study was the first to assess the role played by resinosis on the flammability of tree barks by examining the bark's chemical compounds. Although our results support conventional thinking that resin and oil are strong drivers of the ignition requirements for bark, the chemical allocation has also been found to be a significant factor for assessing fuel flammability [31].

Our results indicated that the resinosis of MP significantly alters the chemistry and flammability of MP barks. Holocellulose, which has a high relative molecular mass, is known to be more thermally stable. A high ash content reduces the fuel flammability and the fuel's contact with oxygen, as only the organic part of the fuel supports combustion [32]. In contrast, the extractive ( $30 \mathrm{~mL}$ ether) has a low relative molecular mass and is known to be relatively volatile and flammable. These changes in the bark's chemistry indicate that the inherent ignitability of barks from MP without resinosis on boles is lower than that of the trees with resinosis.

Characteristic changes to the fuel conditions within affected stands over the course of pest infection have been widely documented in the literature [33-36]. We found that the interactions between bark beetles and coniferous trees were mentioned the most frequently; other interactions were not found in the literature [15]. Conifers are more likely to produce large amounts of resins, which further increase dramatically when the trees are infected, showing that resins play an important role in the tree's defense against pests [37,38]. However, resins are highly flammable, which is an important reason for some of the pestinduced forest fuels (e.g., barks from MP with resinosis) are highly flammable [33,35]. It is worth mentioning that pests' influence on fuels are diverse; the influence could be on fuel profiles, fuel loadings, fuel flammability, fuel bed properties, and fuel chemistry. 


\subsection{Changes of Fire Ecology and Prediction}

As global warming becomes more evident and as wildfires cause huge threats to human life and property, fire prediction and hazard assessment have become increasingly urgent and necessary [39-42]. The severity and scale of pest outbreaks have caused concerns among forest managers, politicians, firefighters, and ecologists about the potential impact of the pest-induced fuel on fire occurrence, severity, and behavior. Coupling pests and fuel is helpful to assess and mitigate fire hazards [43,44]. Our results showed that the resinosis of MP could significantly increase the probability of bark fire occurrence, even though bark is an important organ of tree resistance to fire $[18,20,22]$. The data collected during the field surveys in 2017 indicated that resinosis is more prominent at the bottom bole than at the top bole, and it is also noted that the stem surface facing the southwest is more likely to be affected by pests. The ignition of barks is fatal to coniferous trees and the effects of resinosis on the bark's flammability could weaken its fire resistance and increase the mortality of MP trees [20,45], signifying how potential fire behavior, fire severity, and fire ecology are influenced by the resinosis of MP $[46,47]$. The flammability property test on barks in this study indicates that more comprehensive data support and consideration are needed in order to evaluate the forest fire resistance. The fact that close correlations exist between pest, fuel characteristics, fire hazard, and fire behavior could be utilized in fire prediction.

Several methodological matters need further refinements and to be taken into consideration. Using ground material instead of unground samples to conduct the tests entails the loss of the effect of the plant material structure on its relative flammability [46,48]. However, it is impossible for the unground material to uniformly cover the exposed surface of the sample holder, whereas most results normally reported for the cone calorimeter are expressed on a square meter basis. Thus, the ground material and the assumed exposed surface area of the sample holder are applicable to the cone calorimeter. Moreover, the inputs for the Rothermel model and the BEHAVE fire behavior prediction model are specified as flammability property data (such as the heat content) from vegetation samples that have been ground. Thermal analyses of the ground material have long been performed in order to characterize the flammability of forest fuel. The ground sample is more homogenized and burns more completely, but it is necessary to wrap the sample holder with aluminum foil in order to avoid ground material scattering and sample MLR errors caused by air convection during the combustion process. Nevertheless, aluminum foil may affect the heating of the samples. There remains a gap regarding the extrapolation of the cone calorimeter results for ground material to predict fire behavior in the field.

\section{Conclusions}

Fire ecology and fire prediction for pest-induced fuels represent a great unknown to both forest fire managers and ecologist. This study evaluated the changes caused by pests regarding the fire risks of MP stands. Our study provides new insights into fire and pest management based on bark flammability in MP forests. This study demonstrated the relative importance of pest influences on potential fires in MP forests. Global warming and frequent extreme weather conditions have a negative impact on forest health; frequent drought, fire, and frost result in forest vulnerability to pest attacks that cause a decline in ecological shelters. Our study empirically showed strong associations between resinosis on MP boles and fire susceptibility: the accumulation of pest-induced resin and chemical changes in the barks increased the bark's flammability and made healthy stands more susceptible to fire. Therefore, forest fire risk is high for the forests with resinosis, and the role that pests play in fire-prone forests should receive more attention.

Author Contributions: Conceptualization, Y.W., L.Z., and Y.X.; methodology, Y.W. and J.N.; software, D.H. and H.Y.; validation, G.Y., X.D., and Z.S.; formal analysis, Y.W.; investigation, L.Z.; resources, Y.W.; data curation, L.Z.; writing-original draft preparation, Y.W.; writing-review and editing, G.Y.; visualization, X.D. and J.N.; supervision, G.Y.; project administration, G.Y.; funding acquisition, G.Y. and X.D. All authors have read and agreed to the published version of the manuscript. 
Funding: This work was supported by the National Key R\&D Program of China during the 13th Five-Year Period (2018YFD0600205) and the Fundamental Research Funds for the Central Universities (2572019BA05).

Institutional Review Board Statement: Not applicable.

Informed Consent Statement: Not applicable.

Data Availability Statement: Data is contained within the article.

Acknowledgments: We would like to thank the staff of the Honghuaerji Forest Bureau for their support and sampling assistance throughout the project.

Conflicts of Interest: The authors declare no conflict of interest.

\section{References}

1. Zheng, X.; Zhu, J.J.; Yan, Q.L.; Song, L.N. Effects of land use changes on the groundwater table and the decline of Pinus sylvestris var. mongolica plantations in southern Horqin Sandy Land, Northeast China. Agric. Water Manag. 2012, 109, 94-106. [CrossRef]

2. Song, L.; Zhu, J.; Li, M.; Zhang, J.; Lv, L. Sources of water used by Pinus sylvestris var. mongolica trees based on stable isotope measurements in a semiarid sandy region of Northeast China. Agric. Water Manag. 2016, 164, 281-290. [CrossRef]

3. Zhu, J.; Li, F.; Xu, M.; Kang, H.; Wu, X. The role of ectomycorrhizal fungi in alleviating pine decline in semiarid sandy soil of northern China: An experimental approach. Ann. For. Sci. 2008, 65, 304. [CrossRef]

4. Deng, J.; Li, J.; Deng, G.; Zhu, H.; Zhang, R. Fractal scaling of particle-size distribution and associations with soil properties of Mongolian pine plantations in the Mu Us Desert, China. Sci. Rep. 2017, 7, 6742. [CrossRef]

5. Xu, D.; Chen, B.; Yan, Y.; Sun, X.; Xin, X. Spatial-temporal dynamic monitoring of Mongolian pine (Pinus sylvestris var. mongolica) based on remote sensing data. Remote. Sens. Lett. 2018, 9, 1079-1088. [CrossRef]

6. Song, L.; Zhu, J.; Li, M.; Zhang, J.; Li, D. Water use strategies of natural Pinus sylvestris var. Mongolica trees of different ages in Hulunbuir Sandy Land of Inner Mongolia, China, based on stable isotope analysis. Trees-Struct. Funct. 2018, 32, $1001-1011$. [CrossRef]

7. Zhu, J.; Li, F.; Xu, M.; Kang, H.; Wu, X. Comparison of stand structure and growth between artificial and natural forests of Pinus sylvestiris var. mongolica on sandy land. J. For. Res. 2003, 14, 103-111. [CrossRef]

8. Dulamsuren, C.; Hauck, M.; Leuschner, C. Seedling emergence and establishment of Pinus sylvestris in the Mongolian foreststeppe ecotone. Plant Ecol. 2013, 214, 139-152. [CrossRef]

9. Tang, Y.; Li, X. Simulating effects of precipitation and initial planting density on population size of Mongolian pine in the Horqin Sandy Land, China. Agrofor. Syst. 2018, 92,1-9. [CrossRef]

10. Tang, Y.; Jin, S.; Zhang, X.; Wang, M.; Alberto Busso, C. Estimating the transpiration of Pinus sylvestris trees: From an individual to a stand scale. Biocell 2015, 39, 15-23.

11. Doblas-Miranda, E.; Martinez-Vilalta, J.; Lloret, F.; Alvarez, A.; Avila, A.; Bonet, F.J.; Brotons, L.; Castro, J.; Curiel Yuste, J.; Diaz, M.; et al. Reassessing global change research priorities in mediterranean terrestrial ecosystems: How far have we come and where do we go from here? Glob. Ecol. Biogeogr. 2015, 24, 25-43. [CrossRef]

12. Fernandes, P.M.; Vega, J.A.; Jimenez, E.; Rigolot, E. Fire resistance of European pines. Forest Ecol. Manag. 2008, 256, $246-255$. [CrossRef]

13. Moreira, F.; Viedma, O.; Arianoutsou, M.; Curt, T.; Koutsias, N.; Rigolot, E.; Barbati, A.; Corona, P.; Vaz, P.; Xanthopoulos, G.; et al. Landscape-wildfire interactions in southern Europe: Implications for landscape management. J. Environ. Manag. 2011, 92, 2389-2402. [CrossRef] [PubMed]

14. Yu, H.; Wiegand, T.; Yang, X.; Ci, L. The impact of fire and density-dependent mortality on the spatial patterns of a pine forest in the Hulun Buir sandland, Inner Mongolia, China. For. Ecol. Manag. 2009, 257, 2098-2107. [CrossRef]

15. Jenkins, M.J.; Runyon, J.B.; Fettig, C.J.; Page, W.G.; Bentz, B.J. Interactions among the Mountain Pine Beetle, Fires, and Fuels. For. Sci. 2014, 60, 489-501. [CrossRef]

16. Chen, G.; Metz, M.R.; Rizzo, D.M.; Meentemeyer, R.K. Mapping burn severity in a disease-impacted forest landscape using Landsat and MASTER imagery. Int. J. Appl. Earth Obs. 2015, 40, 91-99. [CrossRef]

17. Brando, P.M.; Nepstad, D.C.; Balch, J.K.; Bolker, B.; Christman, M.C.; Coe, M.; Putz, F.E. Fire-induced tree mortality in a neotropical forest: The roles of bark traits, tree size, wood density and fire behavior. Glob. Chang. Biol. 2012, 18, 630-641. [CrossRef]

18. Pausas, J.G. Bark thickness and fire regime. Funct. Ecol. 2015, 29, 315-327. [CrossRef]

19. Pellegrini, A.F.A.; Anderegg, W.R.L.; Paine, C.E.T.; Hoffmann, W.A.; Kartzinel, T.; Rabin, S.S.; Sheil, D.; Franco, A.C.; Pacala, S.W. Convergence of bark investment according to fire and climate structures ecosystem vulnerability to future change. Ecol. Lett. 2017, 20, 307-316. [CrossRef] 
20. Frejaville, T.; Curt, T.; Carcaillet, C. Bark flammability as a fire-response trait for subalpine trees. Front. Plant Sci. 2013,4 , 466. [CrossRef]

21. Bauer, G.; Speck, T.; Bloemer, J.; Bertling, J.; Speck, O. Insulation capability of the bark of trees with different fire adaptation. J. Mater. Sci. 2010, 45, 5950-5959. [CrossRef]

22. Lawes, M.J.; Richards, A.; Dathe, J.; Midgley, J.J. Bark thickness determines fire resistance of selected tree species from fire-prone tropical savanna in north Australia. Plant Ecol. 2011, 212, 2057-2069. [CrossRef]

23. Ryan, K.; de Groot, P.; Smith, S.M.; Turgeon, J.J. Seasonal occurrence and spatial distribution of resinosis, a symptom of Sirex noctilio (Hymenoptera: Siricidae) injury, on boles of Pinus sylvestris (Pinaceae). Can. Entomol. 2013, 145, 117-122. [CrossRef]

24. Xu, D.; Wang, S.; Wang, Y.; Liu, Y.; Dong, C.; Jiang, Z.; Zhu, P. Preparation and Mechanism of Flame-Retardant Cotton Fabric with Phosphoramidate Siloxane Polymer through Multistep Coating. Polymers 2020, 12, 1538. [CrossRef]

25. White, R.H.; Zipperer, W.C. Testing and classification of individual plants for fire behaviour: Plant selection for the wildland-urban interface. Int. J. Wildland Fire 2010, 19, 213-227. [CrossRef]

26. Landesmann, J.B.; Tiribelli, F.; Paritsis, J.; Veblen, T.T.; Kitzberger, T. Increased fire severity triggers positive feedbacks of greater vegetation flammability and favors plant community-type conversions. J. Veg. Sci. 2020, 32, e12936. [CrossRef]

27. Madrigal, J.; Hernando, C.; Guijarro, M.; Diez, C.; Marino, E.; de Castro, A.J. Evaluation of Forest Fuel Flammability and Combustion Properties with an Adapted Mass Loss Calorimeter Device. J. Fire Sci. 2009, 27, 323-342. [CrossRef]

28. Weise, D.R.; White, R.H.; Beall, F.C.; Etlinger, M. Use of the cone calorimeter to detect seasonal differences in selected combustion characteristics of ornamental vegetation. Int. J. Wildland Fire 2005, 14, 321-338. [CrossRef]

29. ISO [International Organization for Standardization]. ISO 5660-1: 2015. In Reaction-to-Fire Tests—Heat Release, Smoke Production and Mass Loss Rate-Part 1: Heat Release Rate (Cone Calorimeter Method) and Smoke Production Rate (Dynamic Measurement); ISO: Geneva, Switzerland, 2015.

30. Xie, H.; Fawcett, J.E.; Wang, G.G. Fuel dynamics and its implication to fire behavior in loblolly pine-dominated stands after southern pine beetle outbreak. For. Ecol. Manag. 2020, 466, 118130. [CrossRef]

31. Jolly, W.M.; Parsons, R.A.; Hadlow, A.M.; Cohn, G.M.; Mcallister, S.S.; Popp, J.B.; Hubbard, R.M.; Negron, J.F. Relationships between moisture, chemistry, and ignition of Pinus contorta needles during the early stages of mountain pine beetle attack. For Ecol. Manag. 2012, 269, 52-59. [CrossRef]

32. Philpot, C.W. Influence of Mineral Content on the Pyrolysis of Plant Materials. For. Sci. 1970, 16, 461-471. [CrossRef]

33. Schoennagel, T.; Veblen, T.T.; Negron, J.F.; Smith, J.M. Effects of Mountain Pine Beetle on Fuels and Expected Fire Behavior in Lodgepole Pine Forests, Colorado, USA. PLoS ONE 2012, 7, e30002. [CrossRef] [PubMed]

34. Jorgensen, C.A.; Jenkins, M.J. Fuel Complex Alterations Associated with Spruce Beetle-Induced Tree Mortality in Intermountain Spruce/Fir Forests. For. Sci. 2011, 57, 232-240.

35. Jenkins, M.J.; Page, W.G.; Hebertson, E.G.; Alexander, M.E. Fuels and fire behavior dynamics in bark beetle-attacked forests in Western North America and implications for fire management. For. Ecol. Manag. 2012, 275, 23-34. [CrossRef]

36. Hoffman, C.; Morgan, P.; Mell, W.; Parsons, R.; Strand, E.K.; Cook, S. Numerical Simulation of Crown Fire Hazard Immediately after Bark Beetle-Caused Mortality in Lodgepole Pine Forests. For. Sci. 2012, 58, 178-188. [CrossRef]

37. Ott, D.S.; Yanchuk, A.D.; Huber, D.P.W.; Wallin, K.F. Genetic Variation of Lodgepole Pine, Pinus contorta var. latifolia, Chemical and Physical Defenses that Affect Mountain Pine Beetle, Dendroctonus ponderosae, Attack and Tree Mortality. J. Chem. Ecol. 2011, 37, 1002-1012. [CrossRef]

38. Boone, C.K.; Aukema, B.H.; Bohlmann, J.; Carroll, A.L.; Raffa, K.F. Efficacy of tree defense physiology varies with bark beetle population density: A basis for positive feedback in eruptive species. Can. J. For. Res. 2011, 41, 1174-1188. [CrossRef]

39. Bradstock, R.; Penman, T.; Boer, M.; Price, O.; Clarke, H. Divergent responses of fire to recent warming and drying across south-eastern Australia. Glob. Chang. Biol. 2014, 20, 1412-1428. [CrossRef]

40. Stojanova, D.; Kobler, A.; Ogrinc, P.; Zenko, B.; Dzeroski, S. Estimating the risk of fire outbreaks in the natural environment. Data Min. Knowl. Disc. 2012, 24, 411-442. [CrossRef]

41. Westerling, A.L.; Hidalgo, H.G.; Cayan, D.R.; Swetnam, T.W. Warming and earlier spring increase western US forest wildfire activity. Science 2006, 313, 940-943. [CrossRef]

42. Sadasivuni, R.; Cooke, W.H.; Bhushan, S. Wildfire risk prediction in Southeastern Mississippi using population interaction. Ecol. Model. 2013, 251, 297-306. [CrossRef]

43. Jenkins, M.J.; Hebertson, E.; Page, W.; Jorgensen, C.A. Bark beetles, fuels, fires and implications for forest management in the Intermountain West. For. Ecol. Manag. 2008, 254, 16-34. [CrossRef]

44. Hicke, J.A.; Johnson, M.C.; Jane, L.H.D.; Preisler, H.K. Effects of bark beetle-caused tree mortality on wildfire. For. Ecol. Manag. 2012, 271, 81-90. [CrossRef]

45. Madrigal, J.; Souto-Garcia, J.; Calama, R.; Guijarro, M.; Picos, J.; Hernando, C. Resistance of Pinus pinea L. bark to fire. Int. J. Wildland Fire 2019, 28, 342-353. [CrossRef]

46. Dibble, A.C.; White, R.H.; Lebow, P.K. Combustion characteristics of north-eastern USA vegetation tested in the cone calorimeter: Invasive versus non-invasive plants. Int. J. Wildland Fire 2007, 16, 426-443. [CrossRef] 
47. Yospin, G.I.; Bridgham, S.D.; Kertis, J.; Johnson, B.R. Ecological correlates of fuel dynamics and potential fire behavior in former upland prairie and oak savanna. For. Ecol. Manag. 2012, 266, 54-65. [CrossRef]

48. White, R.H.; Weise, D.R.; Mackes, K.; Dibble, A.C. Cone calorimeter testing of vegetation-An update. In Proceedings of the ThirtyFifth International Conference on Fire Safety, Seventeenth International Conference on Thermal Insulation, Columbus, OH, USA, 22-24 July 2002. Available online: https:/ / www.fpl.fs.fed.us/documnts/pdf2002/white02b.pdf (accessed on 19 March 2021). 